\title{
Development and Application of Loop-Mediated Isothermal Amplification Assay for Rapid Detection of Fusarium Oxysporum f. Sp. lycopersici
}

Mohammad Amin Almasi ${ }^{1 *}$, Seyed Mohammad Hosseini Dehabadi ${ }^{2}$, Aboubakr Moradi $^{1}$, Zahra Eftekhari ${ }^{3}$, Mehdi Aghapour Ojaghkandi ${ }^{1}$ and Saeedeh Aghaei ${ }^{1}$

${ }^{1}$ Department of Biotechnology, Research Institute of Physiology and Biotechnology, University of Zanjan, Zanjan, Iran

${ }^{2}$ Young Researchers and Elite Club, Meybod Branch, Islamic Azad University, Meybod, Iran

${ }^{3}$ Department of Plant Breeding, Research Institute of Agriculture, University of Mohaghegh Ardebili, Ardebil, Iran

\begin{abstract}
A reliable and rapid pathogen detection protocol that utilizes colorimetric loop-mediated isothermal amplification (LAMP) was developed for detection of Fusarium oxysporum $f$. sp. lycopersici In this regard, all four LAMP primers (i.e. F3, B3, FIP and BIP) together with PCR primers (F and B) were designed based on conserved sequence of 28s ribosomal RNA gene which conserve between Fusarium oxysporum $\mathrm{f}$. sp. lycopersici isolates (GenBank accession number: HM057281.1). Even though PCR and LAMP assays could successfully detect positive infected samples, considering the time, safety, cost and simplicity, the latter was overall superior. Furthermore, the results demonstrated that the LAMP assay was more sensitive and faster compared to PCR. Interestingly, LAMP reaction could successfully detect Fusarium oxysporum $f$. sp. lycopersici without DNA purification (direct-LAMP). Meanwhile, among six visual dyes used to detect LAMP products, hydroxynaphthol blue, GeneFinder ${ }^{\mathrm{TM}}$ and SYBR Green I could produce long stable color change and brightness in a close tube-based approach to prevent cross-contamination risk. Altogether, as LAMP is sensitive, cost effective, fairly user friendly and also can generate more accurate results than previous diagnostic procedures such as serological methods, PCR and other molecular methods, we accordingly propose this colorimetric assay as a highly reliable alternative fungi recognition system regarding Fusarium oxysporum $f$. sp. lycopersici recognition and probably other fungi-based diseases.
\end{abstract}

Keywords: Colorimetric assay; Direct LAMP assay; Fusarium oxysporum f. sp. lycopersici; LAMP assay; PCR assay

\section{Introduction}

Tomato (Lycopersicon esculentum Mill.) is one of the most common and economically important vegetable crops in many growing regions of the world, which is parasitized by a number of pathogens. Members of the Fusarium oxysporum species complex (FOSC) are the most common phytopathogenic Fusaria that cause vascular wilts of over 100 cultivated plant species [1]. Fusarium oxysporum Schlechtend: Fr. f. sp. lycopersici (Sacc.) W.C. Snyder and H.N. Hansen, the causal vascular wilt of tomato, is one of the most economically important and widespread diseases of the cultivated tomato [2]. The causal agent of fusarium wilt is soil borne pathogen which can persist many years in the soil without a host. The virulence profile of F. oxysporum f. sp. lycopersici isolates affecting tomatoes has been grouped into three races according to their ability to infect a set of differential cultivars carrying distinct resistance loci (race 1, 2 and 3) [3-6]. Races 1 and 2 are distributed throughout the world whereas race 3 has a more limited geographic distribution [7]. Based on the sequence analysis of IGS of the race 1 , it is observed that there is at least $95 \%$ similarity between the races 1,2 and $3[8]$.

An inoculation assay using tester plants has been a popular approach for an identification of forma specials. However, this is a timeconsuming approach; thus necessitating development of other methods [9]. Baayen et al. [10] have proposed immunoassays as alternative methods while recently, molecular markers have become popular for identifying species and subspecies in fungi. Some of the techniques that have been reported include amplified fragment length polymorphisms (AFLP) [11], random amplified polymorphic DNA (RAPD) [12], polymerase chain reaction (PCR) [13] and restriction fragment length polymorphisms (RFLP) [10].

Among various isothermal amplification systems developed over the recent years, the most frequently applied approach seems to be loop-mediated isothermal amplification (LAMP), implemented first by Notomi [14]. Briefly, each reaction is carried out four oligonucleotide primers which recognize six distinct regions on the target DNA in conjunction with two loop primers to accelerate the reaction [14-17]. LAMP assay can also amplify nucleic acid under isothermal condition in the range of 60 to $65^{\circ} \mathrm{C}$, all turbidity- and fluorescent-based detections, as well as agarose gel electrophoresis system are applied to visualize suspicious samples [15]. LAMP-positive amplicons confirmed by adding a number of fluorescent dsDNA intercalating dye including ethidium bromide $[18,19]$, SYBR Green I [20] and propidium iodide [21] after the reaction is completed or metal indicators such as calcein [22], GeneFinder ${ }^{\mathrm{TM}}$ [23], hydroxynaphthol blue (HNB) [24-26] and magnesium pyrophosphate $[14,18,27]$ prior to the reaction, allowing observation with the naked eye [28,29]. LAMP assay was widely applied for detection of many important infectious diseases in human and animals [30]. Furthermore, several researches on detection of bacterial, fungal and viral plant pathogens have been carried out [3133]. Recently, valuable studies for detection of Fusarium have been published by the LAMP assay [34-37]. Thus, it is potent technique for detection of fungal plant pathogens.

*Corresponding author: Mohammad Amin Almasi, Department of Biotechnology, Research Institute of Physiology and Biotechnology, University of Zanjan, Zanjan, Iran, E-mail: aminalmasi63@yahoo.com

Received May 08, 2013; Accepted May 20, 2013; Published May 25, 2013

Citation: Almasi MA, Dehabadi SMH, Moradi A, Eftekhari Z, Ojaghkandi MA, et al. (2013) Development and Application of Loop-Mediated Isothermal Amplification Assay for Rapid Detection of Fusarium Oxysporum f. Sp. lycopersici. J Plant Pathol Microb 4: 177 doi:10.4172/2157-7471.1000177

Copyright: (c) 2013 Almasi MA, et al. This is an open-access article distributed under the terms of the Creative Commons Attribution License, which permits unrestricted use, distribution, and reproduction in any medium, provided the original author and source are credited. 
Citation: Almasi MA, Dehabadi SMH, Moradi A, Eftekhari Z, Ojaghkandi MA, et al. (2013) Development and Application of Loop-Mediated Isothermal Amplification Assay for Rapid Detection of Fusarium Oxysporum f. Sp. Iycopersici. J Plant Pathol Microb 4: 177 doi:10.4172/21577471.1000177

The aim of this research was to develop a rapid and sensitive colorimetric LAMP protocol based on six different visualization systems for detection and identification of Fusarium oxysporum f. sp. Lycopersici.

\section{Materials and Methods}

\section{Fungi samples and DNA extraction}

The samples of diseased tomato plants showing the symptoms of tomato wilt were collected from different tomato varieties in different provinces (Tehran, Shiraz, Kerman, Khozestan, Hamadan, Markazi, Esfahan, Kermanshah, Zanjan and Mashhad) where tomatoes are commonly grown in Iran from 2010-2011 growing season. The diseased plants and fruits were analyzed in the laboratory and pathogen isolation was subsequently performed there as well. Also, fruits with symptoms of fusarium wilt were collected from the warehouse during summer and autumn of 2011 and isolation of pathogen was carried out by cutting the fragments, at the border of diseased and healthy tissue [2]. The fragments were surface sterilized with $3 \% \mathrm{NaOCl}$ for $3 \mathrm{~min}$, transferred on potato dextrose agar (PDA) and incubated at $25^{\circ} \mathrm{C}$ for seven days. Growth characteristics of cultures were studied on PDA and Czapek agar. The cultures were incubated in $90 \mathrm{~mm}$ Petri dishes at $25^{\circ} \mathrm{C}$ in dark, for 7 days. Petri box isolates were then transferred to a thermostat with artificial UV light, at a temperature of $25^{\circ} \mathrm{C}$ for 10 days, to induce sporulation and pigmentation in culture [38]. The light source consisted of three neon tubes measuring $40 \mathrm{~W}$ and a black tube 'black light' (Philips TLD 36W/08). Whether or not the isolates belonged to the species Fusarium oxysporum was determined by PCR. The selected isolates were transferred into Petri dishes on PDA medium and allowed to grow for $72 \mathrm{~h}$ at $25^{\circ} \mathrm{C}$. After incubation the mycelium was scraped off and transferred to Eppendorf tubes for DNA extraction. The isolation of DNA was performed according to Cenis [39]. The mycelial mat was pelleted by centrifugation for $5 \mathrm{~min}$ at $13000 \mathrm{rpm}$, then washed with $500 \mu \mathrm{l}$ of TE buffer and pelleted again. The TE was decanted and 300 $\mu \mathrm{l}$ of extraction buffer $(200 \mathrm{mM}$ Tris $\mathrm{HCl} \mathrm{pH} \mathrm{8.5,} 250 \mathrm{mM} \mathrm{NaCl}, 25$ mM EDTA and $0.5 \%$ SDS) were added. The mycelium was crushed with conical grinder following by several steps of washing and precipitation. After a wash with 70\% ethanol, the pellet was dried and resuspended in $50 \mu$ of TE.

\section{Development of primers for PCR and LAMP}

\begin{tabular}{|c|c|c|c|c|c|}
\hline Assay & Primer & Type & $\begin{array}{l}\text { Position on } \\
\text { gene }\end{array}$ & Length & Sequence $\left(5^{\prime}-3^{\prime}\right)$ \\
\hline \multirow[t]{2}{*}{ PCR } & $\mathrm{F}$ & Forward & $1698-1717$ & $20 \mathrm{mer}$ & $\begin{array}{l}\text { GATTCGCCTTGGTC- } \\
\text { GAAATA }\end{array}$ \\
\hline & B & Backward & $1908-1927$ & 20mer & $\begin{array}{l}\text { GGTTTGTCCT- } \\
\text { CACCCTITCA }\end{array}$ \\
\hline \multirow[t]{6}{*}{ LAMP } & F3 & Forward outer & $1014-1031$ & $18 \mathrm{mer}$ & $\begin{array}{l}\text { GCCTGGATTCTG- } \\
\text { GTGTGG }\end{array}$ \\
\hline & B3 & Backward outer & $1169-1186$ & $18 \mathrm{mer}$ & $\begin{array}{l}\text { CCGTCCCAGCCAA- } \\
\text { GATCA }\end{array}$ \\
\hline & $\begin{array}{l}\text { FIP (Forward } \\
\text { inner primers) }\end{array}$ & $\begin{array}{l}\text { F1c (Forward } \\
\text { inner) }\end{array}$ & 1077-1099 & 23mer & $\begin{array}{l}\text { TACCAGACGTCTG- } \\
\text { GCTACCCTGT }\end{array}$ \\
\hline & & $\begin{array}{l}\text { F2 (Forward } \\
\text { inner) }\end{array}$ & $1033-1051$ & $19 \mathrm{mer}$ & $\begin{array}{l}\text { GTAGGGTAGGGTAG- } \\
\text { GCGTA }\end{array}$ \\
\hline & $\begin{array}{l}\text { BIP } \\
\text { (Backward } \\
\text { inner primers) }\end{array}$ & $\begin{array}{l}\text { B1c (Backward } \\
\text { inner) }\end{array}$ & $1005-1024$ & 20mer & $\begin{array}{l}\text { ATGGGGGTGTAGGG- } \\
\text { TAGGTC }\end{array}$ \\
\hline & & $\begin{array}{l}\text { B2 (Backward } \\
\text { inner) }\end{array}$ & $1047-1067$ & $22 \mathrm{mer}$ & $\begin{array}{l}\text { TCCTCCCTCGACTA- } \\
\text { AAGCGAAG }\end{array}$ \\
\hline
\end{tabular}

Table 1: Oligonucleotide primers used for LAMP and PCR based on $28 \mathrm{~s}$ ribosomal RNA gene of Fusarium oxysporum $f$. sp. lycopersici.

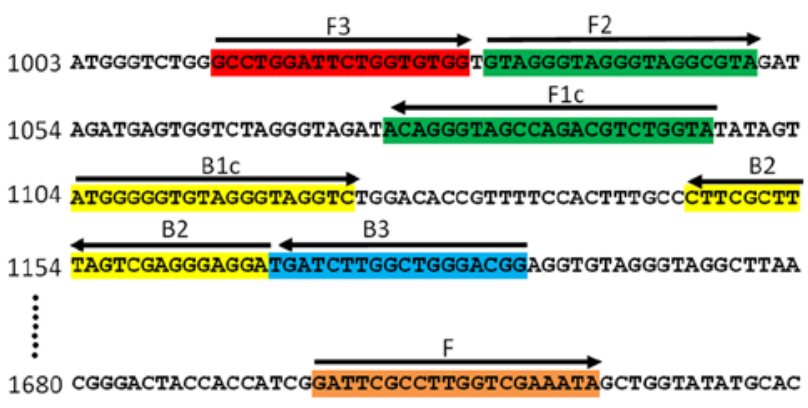

1731 TTTTGAAAAAATGCGTGCAAAATGGTTTTGTGGTTTGGTGGCTGTGAGTCG

1781 ATTTTTTTGTTTTCCCATACAAATGAATTTTGCGGAAAATAAAAAGTGGCC

1831 CACGAGGCAGTCCTGGCGTGCGGCCCACTAAAACGGTCTCGGAGGGTATAT $\mathrm{R}$

1881 GAGAAGGGAGCAAATCCGGCCGAGCCTGAAAGGGTGAGGACAAACCGGGCG

Figure 1: Schematic representation of position and sequence of $28 \mathrm{~s}$ ribosomal RNA gene of Fusarium oxysporum $f$. sp. lycopersici specific primers used in PCR and LAMP analysis.

PCR and LAMP assays were developed using Fusarium oxysporum $f$. sp. lycopersici specific primers designed based on conserved sequence of 28s ribosomal RNA gene (GenBank accession number: HM057281.1). Designed primers and primer positions on gene, for PCR and LAMP are shown in Table 1. PCR and LAMP specific primers were designed using the Oligo7 and Primer ExplorerV4 software (specific for LAMP) respectively. PCR Forward (F) and Backward (B) Primers were amplified a 233 bp fragment of 28 s ribosomal RNA gene. At LAMP assay a set of four primers recognizing six distinct regions in the target sequence were used, including Outer primers (F3 and $\mathrm{B} 3$ ) and Inner primers (FIP and BIP). Also, F3 and B3 Primers were amplified a 153 bp fragment of 28s ribosomal RNA gene in PCR assay (Figure 1). Moreover, each primer was tested for similarities with other sequences available in the GenBank databases (http://blast.ncbi.nlm.nih.gov/Blast.cgi) using the BlastN algorithm.

PCR assay: PCR assay was developed using a specific primer pair (F and B). PCR was carried out in a Bio-Rad thermocycler. The amplification was performed in a $25 \mu \mathrm{l}$ volume containing $1 \mathrm{X}$ PCR buffer (10 mM Tris-HCL, pH 8.3 and $50 \mathrm{mM} \mathrm{KCl}), 1.5 \mathrm{mM} \mathrm{MgCl}_{2}$, $0.2 \mathrm{mM}$ of each dNTP, 10 pmol of each F and B primers, $1 \mathrm{U}$ of Taq DNA polymerase (Cinagen Co, Cat. No TA7505C) and $2 \mu$ DNA. Amplification was performed with the following PCR profile: $94^{\circ} \mathrm{C}$ for $3 \mathrm{~min}, 30$ cycles of $30 \mathrm{~s}$ at $94^{\circ} \mathrm{C}, 35 \mathrm{~s}$ at $57^{\circ} \mathrm{C}, 55 \mathrm{~s}$ at $72^{\circ} \mathrm{C}$ and $10 \mathrm{~min}$ at $72^{\circ} \mathrm{C}$ for final extension. The products were analyzed by electrophoresis on a $1.5 \%$ agarose gel. Also, the PCR assay was carried out using F3 and B3primers pair separately.

LAMP assay: In order to perform LAMP, four specific primers including outer primers (F3 and B3) and inner primers (FIP and BIP) were designed using PrimerExplorer V4 software (http://primerexplorer. $\mathrm{jp} / \mathrm{e} /)$. LAMP assay was performed in a total volume of $25 \mu \mathrm{l}$ using DNA obtained in a way that we described before. Initially $2 \mu \mathrm{DNA}$ was added to $23 \mu$ of LAMP mixture to provide a final concentration of $20 \mathrm{mM}$ Tris- $\mathrm{HCl}, \mathrm{pH} 8.8,10 \mathrm{mM} \mathrm{KCl}, 10 \mathrm{mM}(\mathrm{NH} 4)_{2} \mathrm{SO}_{4}, 0.1 \%$ Triton X-100, 2 mM Betaine (Sigma-Aldrich, Oakville, Ontario, Canada), 1 $\mathrm{mM} \mathrm{CaCl}, 10 \mathrm{mM}$ each dNTP, $0.2 \mu \mathrm{M}$ each of primer F3 and B3, 0.8 $\mu \mathrm{M}$ each of primer FIP and BIP and $8 \mathrm{U}$ of Bst DNA polymerase (New England Biolabs Inc.). Tubes were then incubated at $60^{\circ} \mathrm{C}$ for $60 \mathrm{~min}$ in 
Citation: Almasi MA, Dehabadi SMH, Moradi A, Eftekhari Z, Ojaghkandi MA, et al. (2013) Development and Application of Loop-Mediated Isothermal Amplification Assay for Rapid Detection of Fusarium Oxysporum f. Sp. Iycopersici. J Plant Pathol Microb 4: 177 doi:10.4172/21577471.1000177

water bath. The products were analyzed by electrophoresis on a $1.5 \%$ agarose gel.

Colorimetric LAMP assay: Here, the validations of positive LAMP reactions were justified by means of six approaches:

Calcium chloride: Like other metal indicators, magnesium pyrophosphate must be added before reaction. At the end of the amplification process, positive reactions were accompanied by a visible darker phase in the tubes in consequence of the formation of magnesium pyrophosphate which can be easily visualized with the naked eye. It is noticeable that the turbidity of the positive samples is stable but just for a short time, which should be consequently judged soon after taking out of the samples from the water bath [14,21,40-42]. Use of $\mathrm{MgCl}_{2}$ or $\mathrm{MgSO}_{4}$ in LAMP reaction in order to create turbidity has some drawbacks such as, low stability and concentration. In this research, we used $\mathrm{CaCl}_{2}$ to address these disadvantages and the reaction was performed according to Almasi et al. [27].

Hydroxynaphthol blue (HNB): In this protocol, $1 \mu \mathrm{l}$ of the hydroxynaphthol blue dye ( $3 \mathrm{mM}$, Lemongreen, Shanghai, China) is mixed prior to amplification; all positive reactions can be easily identified using the naked eye, interestingly with no probable cross contaminations which usually arise from opened tubes after amplification $[24,26,41,42]$. In this context, a sky blue colour pattern implies the existence of the reference virus, whereas a violet colour change is observed when the control(s) are taken into consideration.

GeneFinder ${ }^{\mathrm{TM}}$ : An obvious Green fluorescence pattern was observed to confirm positive LAMP products through visual observation with the naked eye when $1 \mu \mathrm{l}$ of GeneFinder ${ }^{\mathrm{TM}}$, diluted to 1:10 with $6 \times$ loading buffer (TaKara, Dalian, China), was added to each reaction as described previously $[23,41,43]$. Remarkably, concerning negative reaction, the original orange colour could be observed.

SYBR Green I: $1 \mu$ l of SYBR Green I (Invitrogen, Sydney, Australia) diluted to 1:10 with $6 \times$ loading buffer Was separately added to each reaction as described previously [23,44]. Remarkably, concerning negative reaction, the original orange colour could be observed.

SYBR $^{\oplus}$ Premix Ex Taq ${ }^{\mathrm{TM}}$ II: Hence, $2 \mu \mathrm{SYBR}^{\oplus}$ Premix Ex Taq ${ }^{\mathrm{TM}}$ II (Perfect Real Time, Takara Bio Co., Ltd., RR081A) was added into each completely finished LAMP reaction containing $25 \mu \mathrm{l}$ LAMP products; all four positive reactions were effectively identified. Under UV illumination (302 nm), a green colour pattern is an identical characteristic of all positive reactions as the same was monitored in this study $[12,44]$.

Ethidium bromide: About $0.5 \mu$ g ethidium bromide/ml (Sigma) was added to each tube $[19,41]$. Under a UV transilluminator, positive products will be consequently marked if a detectable yellow colour pattern is observed. As a result, the intensity of the fluorescent emissions moves up in positive tubes, while the reverse is true regarding negative tubes with no amplified fragments.

\section{Direct LAMP in PDA medium}

PCR inhibitors are commonly found in medium and inhibit PCR reaction [45]. In contrast, LAMP assay is tolerant against inhibitors in culture medium [46]. To measure the LAMP technique strength, direct detection of Fusarium oxysporum f. sp. lycopersici in PDA medium was fulfilled without prior DNA purification, subsequently, a simple, rapid and inexpensive procedure was applied to directly detect Fusarium oxysporum f. sp. lycopersici in PDA; $0.1 \mathrm{~g}$ of fungal mycelia was removed from the PDA plate culture with a sterile needle and was then dissolved in $300 \mu \mathrm{l}$ distilled water. Afterwards, the solution was centrifuged at $17800 \mathrm{~g}$ for $5 \mathrm{~min}$ at $4^{\circ} \mathrm{C}$ and finally, $2 \mu \mathrm{l}$ supernatant was directly added to the LAMP and PCR reaction mixtures as a template. To avoid or reduce probable errors, all alluded procedures were repeated three times.

\section{Sensitivity and specificity of the LAMP assay}

Both quality and quantity of DNA template may have a dramatic influence on the results of each PCR method. To determine the sensitivity of LAMP reaction different concentrations of DNA $(1 \mathrm{ng} / \mu \mathrm{l}$ up to $1000 \mathrm{ng} / \mu \mathrm{l}$ ) were tested. To determine specificity of the primers, LAMP and PCR reactions were carried out to Fusarium redolens $f$. sp. dianthi, Fusarium tricinctum, Fusarium graminearum. Furthermore,

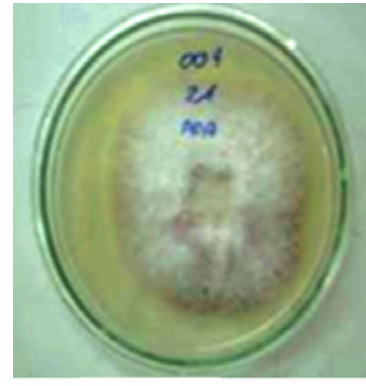

a)

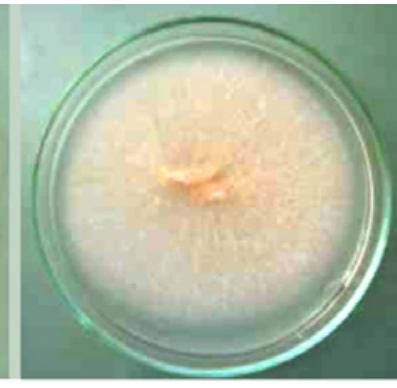

b)
Figure 2: Colonies of Fusarium sp. (a) PDA; (b) Czapek agar.

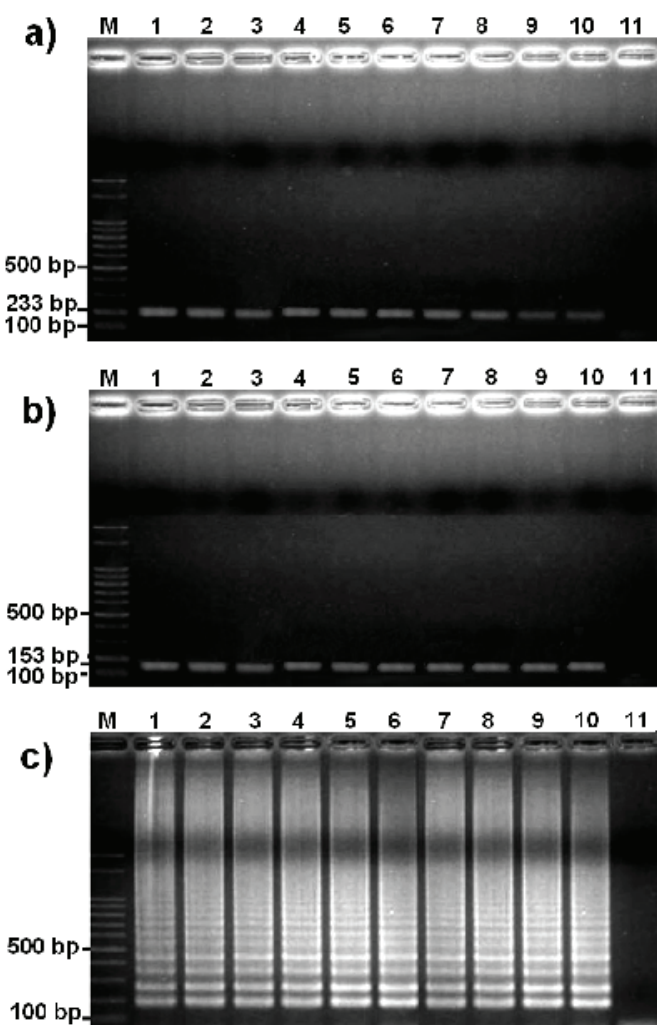

Figure 3: Gel electrophoresis pattern of the PCR and LAMP amplicons on 1.5 $\%$ agarose gel (a) PCR reaction with $F$ and $B$ primers; (b) PCR reaction with $F 3$ and B3 primers; (c) LAMP reaction. Left to right: lane M, DNA size marker (100 bp; Fermentas); lanes 1-10, positive samples, respectively; lane 11 negative control (water). 
Citation: Almasi MA, Dehabadi SMH, Moradi A, Eftekhari Z, Ojaghkandi MA, et al. (2013) Development and Application of Loop-Mediated Isothermal Amplification Assay for Rapid Detection of Fusarium Oxysporum f. Sp. Iycopersici. J Plant Pathol Microb 4: 177 doi:10.4172/21577471.1000177

GeneFinder ${ }^{\mathrm{TM}}$ dye was added to LAMP products and positive reactions were directly detected by visual inspection. Similarly, the detection limit of the LAMP and PCR was approved by electrophoresis on $1.5 \%$ agarose gel.

\section{Results}

On potato-dextrose medium fungus isolated from stem of diseased tomato plants formed a hyaline, branching mycelium that was white to gray. On Czapek agar isolates formed colonies and mycelium appeared as aerial, grey to light purple in color depending on the isolate (Figure 2a). All observed isolates formed macroconidia as eliptical, gradually pointed or curved edges (pointed end). Macroconidia varied in size from 30-60 $\mu \mathrm{m}$ to 3-5 $\mu \mathrm{m}$. Most often they were short and had three septa. They formed a large number of unicellular, elyptical, oval-shaped or kidney-shaped microconidia clustered into so-called false heads. All these characteristics pointed to the isolates being of the species $F$. oxysporum. On PDA medium isolates from diseased stems formed light pink aerial mycelium and red pigment in the agar. Macroconidia were formed, while microconidia or chlamidispores were not. Macroconidia were hyaline, falcate, 3-7 septate (mostly 5 ), $30-60 \times 2-3 \mu \mathrm{m}$ in size (Figure $2 \mathrm{~b}$ ). On the whole, 10 out of 20 collected samples showed positive responses. Regarding PCR, the amplification occurred via both backward and forward primers to generate ultimate products. The method, overall, could successfully identify ten aforementioned positive samples. As expected, a fragment with the size band of 233 bp (with F and B) and 153 bp (with F3 and B3) of 28s ribosomal RNA

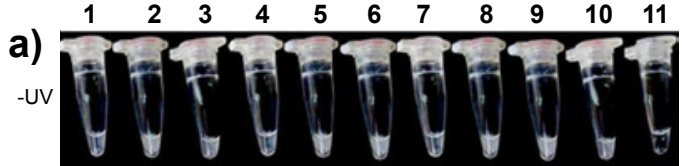

b)

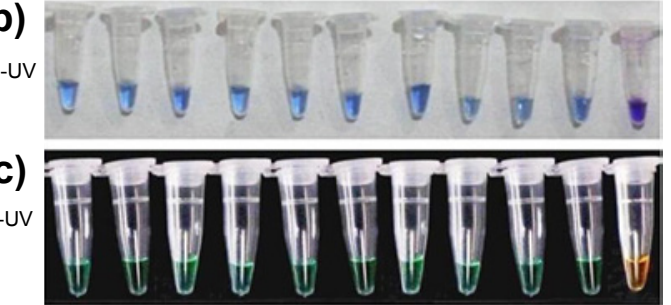

d)
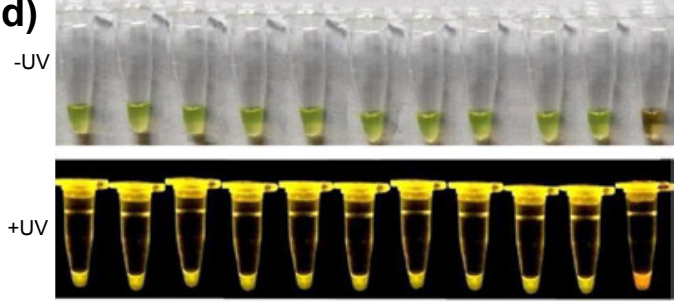

f)

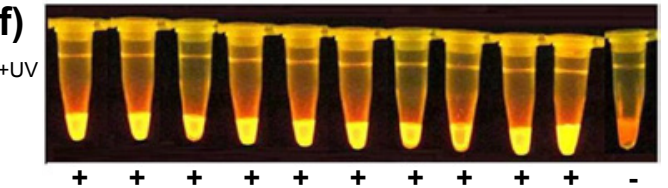

Figure 4: Detection of positive LAMP reactions using five visualizing methods (different dyes) (a) calcium chloride-based method; (b) hydroxynaphthol blue (HNB)-based method; (c) GeneFinder ${ }^{\mathrm{TM}}$ based method; (d) SYBR Green I-based method; (e) SYBR ${ }^{\circledR}$ Premix Ex TaqTM IIbased method; (f) ethidium bromide-based method. Left to right: tubes 1-10, positives samples, respectively; tube 11 negative control (water).

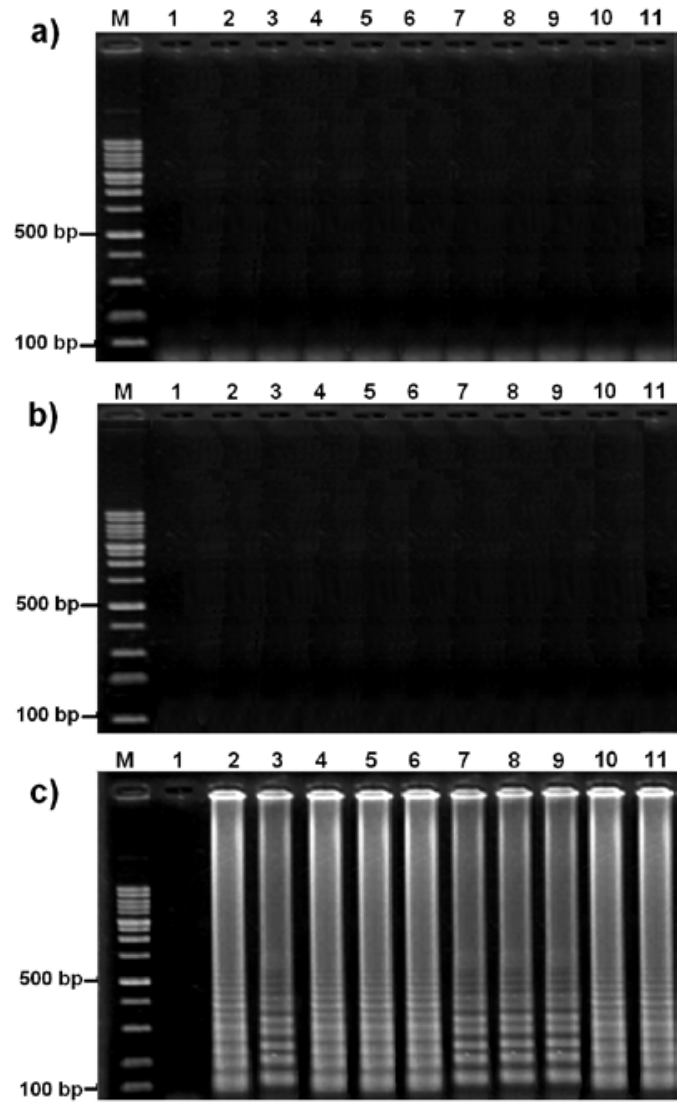

Figure 5: Direct analysis of planting samples without DNA purification (a) PCR reaction with $F$ and $B$ primers; (b) PCR reaction with $\mathrm{F} 3$ and $B 3$ primers; (c) LAMP reaction. Left to right: lane M, DNA size marker (100 bp; Fermentas); lanes 1 negative control (water); lane 2-11, positive sample, respectively.

gene was detected when the PCR products were run on $1.5 \%$ agarose gel and stained with ethidium bromide (Figures $3 \mathrm{a}$ and $3 \mathrm{~b}$ ). The same as PCR, our new LAMP protocol could successfully identify ten positive samples. LAMP amplicons were electrophoresed and a large number of fragments (a ladder-like pattern) were eventually visualized (Figure 3c). LAMP amplicons were able to be detected with the naked eye by adding different visual dyes followed by colour changing in the solutions. In this regard, all used visual components could successfully make a clear distinction between positive infected samples and negative ones (Figures 4a-f). DNA extraction from PDA medium is time-consuming and complicated. Thus, elimination of DNA purification stage can be a critical factor in saving time and capital, especially in detection of pathogens in large samples. Here we used a straight forward and rapid pre-treatment procedure (approximately $5-10 \mathrm{~min}$ ) on fungal mycelia derived from medium before direct-LAMP reaction. The results showed that the samples were successfully detected by LAMP assay within 60 min. However, the turbidity became slightly weaker and reaction time increased slightly compared to standard LAMP method. In contrast, PCR could not detect any target genes since PCR is extremely sensitive to inhibitors derived from medium culture and hence amplification did not occur (Figures 5a-c). Also, whereas LAMP produced a ladder-like pattern, the PCR product was a specific DNA band corresponding to a $233 \mathrm{bp}$ (with F and B primers) or $153 \mathrm{bp}$ (with F3 and B3 primers) amplicons. Our results, interestingly, indicated that LAMP can produce reliable products even under lower DNA concentrations $(50 \mathrm{ng} / \mu \mathrm{l}$ or 
Citation: Almasi MA, Dehabadi SMH, Moradi A, Eftekhari Z, Ojaghkandi MA, et al. (2013) Development and Application of Loop-Mediated Isothermal Amplification Assay for Rapid Detection of Fusarium Oxysporum f. Sp. Iycopersici. J Plant Pathol Microb 4: 177 doi:10.4172/21577471.1000177

Page 5 of 7
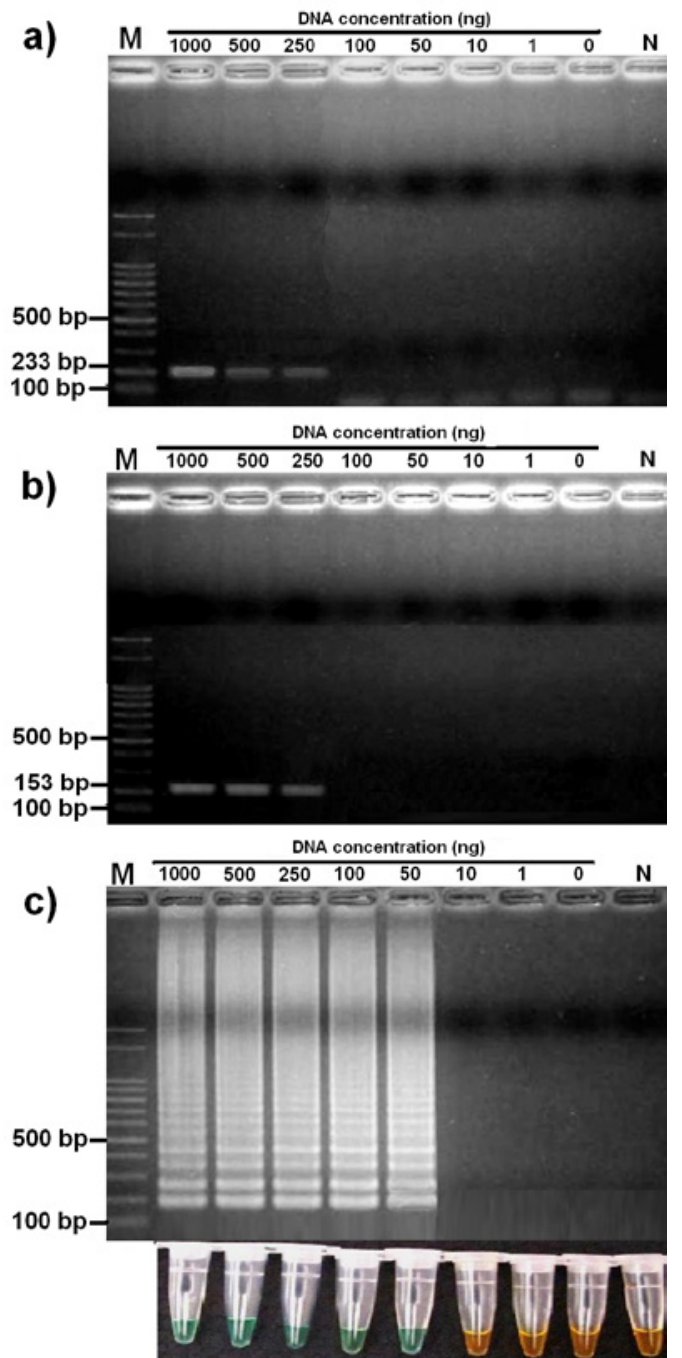

Figure 6: Comparative analysis of the sensitivity of LAMP and PCR, using a seven dilution series of DNA as template (a) Electrophoresis analysis of PCR with F and B primers; (b) Electrophoresis analysis of PCR with F3 and B3 primers; (c) Electrophoresis analysis and visual detection (GeneFinder ${ }^{\mathrm{TM}}$ ) of LAMP. Left to right: Lane M, DNA size marker (100 bp; Fermentas); Lane N negative control (water).

more), whilst PCR, requires higher level of DNA (at least $250 \mathrm{ng} / \mu \mathrm{l}$ ) (Figure $6 \mathrm{a}$ and $6 \mathrm{~b}$ ). Surprisingly, no false positive amplification was detected in specificity test and a $100 \%$ predictive value was obtained for PCR and LAMP assays (Figures 7a-c).

\section{Discussion}

In this study, two detection methods including PCR and LAMP were assessed to explore positive and negative aspects of each one, followed by introducing the best one regarding Fusarium oxysporum f. sp. lycopersici detection. Even though all two techniques had enough potential to make differentiation and detect infected samples accurately, LAMP proved to be much more useful as some factors including time, safety, simplicity, cost and being user friendly are taken into account (Table 2).

LAMP overall requires just $60 \mathrm{~min}$ to accomplish (as the least demanding detection method), while regarding PCR, $3 \mathrm{~h}$ should be served, respectively. This, in turn, would simplify the detection procedure and result in saving of significant time needing for separating of the amplified products on the gel and the analyzing of the data which are commonly used in the other PCR-based methods. Simplicity, cost and user friendly equipped labs with some molecular instruments as well as trained personnel are prerequisites to perform PCR assays, all of which are undoubtedly costly. On the contrary, LAMP can be easily accomplished just in a water bath or temperature block with no need of thermocylcer and gel electrophoresis as the same results were recorded by $[47,48]$. Likewise, exclusive of the primer designing process which is somehow complicated and sensitive, other phases are simply applicable. The strategy is robust, specific and shows tolerance to several biological products that inhibit conventional PCR, meaning that template DNA extraction may not be necessary. Besides, LAMP results can be visually inspected through colour change which significantly reduces the assay time [27,42]. On the other hand, the presence of LAMP positive amplicons proved to be confirmed by adding a number of fluorescent or metal dyes to the reaction tubes, allowing observation with the naked

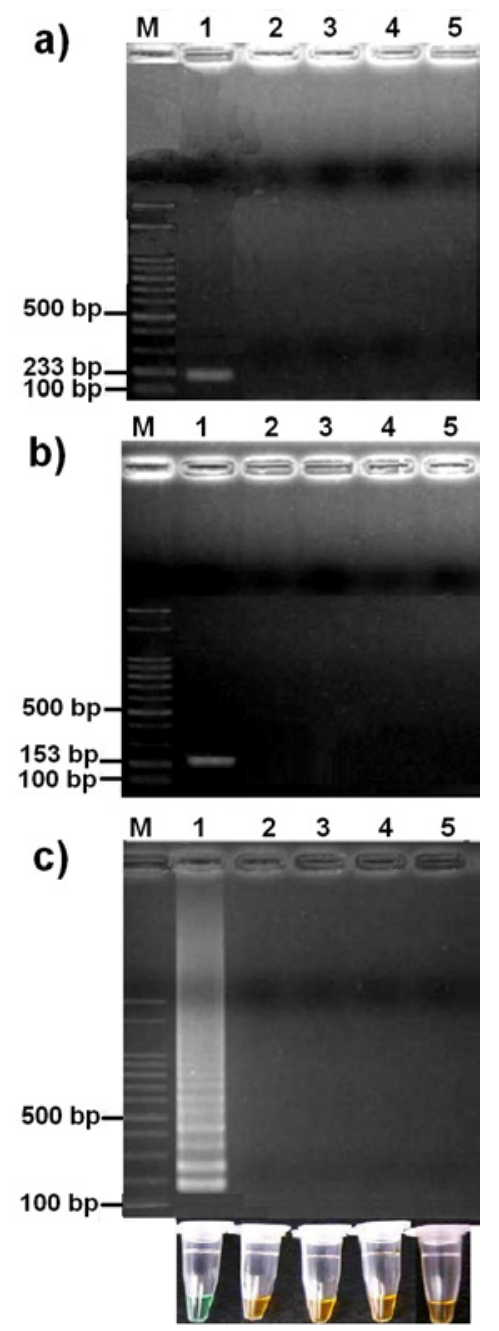

Figure 7: Comparative analysis of the specificity of LAMP and PCR (a) Electrophoresis analysis of PCR with F and B primers; (b) Electrophoresis analysis of PCR with F3 and B3 primers; (c) Electrophoresis analysis and visual detection (GeneFinder ${ }^{\mathrm{TM}}$ ) of LAMP. Left to right: lane M, DNA size marker (100 bp; Fermentas); lane 1 Fusarium oxysporum $f$. sp. lycopersici; lane 2 Fusarium redolens $f$ sp. dianthi; lane 3 Fusarium tricinctum; lane 4 Fusarium graminearum; lane 5 negative control (water). 
Citation: Almasi MA, Dehabadi SMH, Moradi A, Eftekhari Z, Ojaghkandi MA, et al. (2013) Development and Application of Loop-Mediated Isothermal Amplification Assay for Rapid Detection of Fusarium Oxysporum f. Sp. Iycopersici. J Plant Pathol Microb 4: 177 doi:10.4172/21577471.1000177

Page 6 of 7

\begin{tabular}{|l|l|l|l|l|l|l|l|l|l|l|}
\hline Assay & Time & Detection method & Safety & Need to UV ray & $\begin{array}{l}\text { Need to detect } \\
\text { instruments }\end{array}$ & Cost & User Friendly & Accuracy & Sensitivity & Specialty \\
\hline PCR & 3 hours & Gel electrophoresis & No & Yes & Yes & High & Low & High & High & High \\
\hline LAMP & 60 minutes & Visual & Yes & No & No & Low & High & High & Very high & High \\
\hline
\end{tabular}

Table 2: Comparison of PCR and LAMP assays.

\begin{tabular}{|c|c|c|c|c|c|c|c|c|}
\hline Visual system & $\begin{array}{l}\text { Detection } \\
\text { method }\end{array}$ & Safety & $\begin{array}{l}\text { Positive } \\
\text { reaction }\end{array}$ & $\begin{array}{l}\text { Negative } \\
\text { sample }\end{array}$ & $\begin{array}{l}\text { Need to UV } \\
\text { ray }\end{array}$ & Stability & Cross contamination & Use time \\
\hline Calcium chloride & Visual & Yes & Turbidity & No turbidity & No & $\begin{array}{l}40-60 \\
\text { seconds }\end{array}$ & No & Before the amplification \\
\hline Hydroxynaphthol blue & Visual & Yes & Sky blue & Violet & No & 2-3 weeks & No & Before the amplification \\
\hline GeneFinder $^{\mathrm{TM}}$ & Visual & Yes & Green & Red & No & 2-3 weeks & No & Before the amplification \\
\hline SYBR Green I & Visual & Yes & Green & Red & Yes & 2-3 weeks & No & Before the amplification \\
\hline $\begin{array}{l}\text { SYBR }^{\circledR} \text { Premix Ex } \\
\text { TaqTM II }\end{array}$ & Visual & Yes & Green & Red & Yes & $1-3$ days & Yes & After the amplification \\
\hline Ethidium bromide & Visual & No & Yellow & No color & Yes & 2 weeks & Yes & After the amplification \\
\hline
\end{tabular}

Table 3: Comparison of colorimetric assays together.

eye $[25,30,40,49]$. In the current study, therefore, LAMP amplified products were confirmed by adding all aforementioned visual systems (see "Materials and Methods" section), either prior to or after the reaction along with forming diverse color patterns depending upon the chemical characteristics of the applied chemical substances as dye. According to our results, despite the precise detection of positive LAMP products using all dyes, some were significantly superior when the time of stability, cost and the safety were taken into consideration (Table 3). To abbreviate the contamination hazard and also increase colour stability, as a result, two additional metal indicators (i.e. HNB, SYBR Green I and GeneFinder ${ }^{\mathrm{TM}}$ ) known as close-tube LAMP detection were lastly used. The higher specificity and sensitivity of LAMP has already been compared with other nucleic acid-based methods such as PCR $[16,17,43]$. As a consequence, DNA purification stage is time-consuming, troublesome, labor and capital-intensive and it would desirable to eliminate DNA purification. Previous researches have suggested that LAMP assay have shown a significant tolerance to inhibitor substances derived from blood, clinical samples, culture media $[46,50]$, natural materials $[18,51,52]$, and soil [53]. In the current study, the direct-LAMP was successfully developed which is free of DNA purification (samples prepared with minor treatment that merely took 10-20 $\mathrm{min}$ ) and decreased cost, time, labor and also environmentally dangerous reagents. Furthermore, the results obviously exhibited that the LAMP assay to be very minimally affected by inhibitors and reaction successfully took place. This characteristic will make LAMP assay particularly efficient for direct detection in the culture media so directLAMP requires much less technical effort compared to nested-PCR. The results of the present study showed that the LAMP reaction can be completed within $60 \mathrm{~min}$ with about $50 \mathrm{ng} / \mu \mathrm{l}$ DNA concentration while PCR needed at the least $3 \mathrm{~h}$ with about $250 \mathrm{ng} / \mu \mathrm{l}$ DNA concentration to complete a reaction. One may conclude that LAMP works faster with higher sensitivity for detecting of Fusarium oxysporum f. sp. lycopersici compared with PCR.

In summary, a novel colorimetric LAMP assay for rapid and easy detection of Fusarium oxysporum f. sp. Lycopersici was developed here, and then its potential compared with PCR assays. The method, on the whole, had the following advantages over the mentioned procedures and also the method including PCR to detection of Fusarium oxysporum f. sp. Lycopersici: (1) fascinatingly (2), no requirement of expensive and sophisticated tools for amplification and detection; (3) no post-amplification treatment of the amplicons; (4) a flexible and easy detection approach that is visually detected by naked eyes using diverse visual dyes; and (5) a rapid method to detect without the need to DNA purification. On the other hand HNB, SYBR Green I and GeneFinder $^{\mathrm{TM}}$ were proved to be more powerful because of lack of cross contamination, judging positive reactions using the naked eye, no need of post amplification treatment of the amplicons and finally the brightness and stability products. Due to such remarkable features, the application of this colorimetric assay using visual observation systems particularly HNB, SYBR Green I and GeneFinder ${ }^{\mathrm{TM}}$ seems to be more effective as a new fungi diagnostic method for epidemiological studies of Fusarium oxysporum f. sp. lycopersici particularly in less well equipped laboratories. As the last point of view, the current diagnostic approach can be suitable not only for laboratory research but also regarding field diagnoses of many infectious diseases worldwide.

\section{References}

1. Beckman CH (1987) The Nature of Wilt Diseases of Plants, St. Paul, MN, USA APS Press.

2. Ignjatov M, Milosevic D, Nikolic Z, Gvozdanovic-Varga J, Jovicic D, et al. (2012) Fusarium oxysporum as Causal Agent of Tomato Wilt and Fruit Rot. Pestic Phytomed 27: 25-31.

3. Alexander LJ, Hoover MM (1955) Disease resistance in wild species of tomato Ohio Agri Exp Sta Res Bull 752: 1-76.

4. Alexander LJ, Tucker CM (1945) Physiological specialization in the tomato wilt fungus Fusarium oxysporum f. sp. lycopersici. J Agri Res 70: 303-313.

5. Bohn GW, Tucker CM (1940) Studies on Fusarium wilt of the tomato. I Immunity in Lycopersicon pimpinellifolium Mill and its inheritance in hybrids Mis. Agric Exp Sta Res Bull 311: 82

6. Grattidge R (1982) Occurrence of a third race of Fusarium wilt of tomatoes in Queensland. Plant Dis 66: 165-166.

7. Summerell BA, Salleh B, Leslie JF (2003) A utilitarian approach to Fusarium identification. Plant Dis 87: 117-128.

8. Balogun OS (2007) Comparison of Fusarium oxysporum fsp lycopersici races 1,2 and 3 , and $f . s p$ radicis lycopersici based on the sequences of fragments of the ribosomal DNA intergenic spacer region. Biochem 19: 1-8.

9. Woo SL, Zoina A, Del Sorbo G, Lorito M, Nanni B, et al. (1996) Characterization of Fusarium oxysporum f.sp phaseoli by pathogenic races, VCGs, RFLPs, and RAPD. Phytopathol 86: 966-973.

10. Baayen RP, Van Dreven F, Krijger MC, Waalwijk C (1997) Genetic diversity in Fusarium oxysporum f.sp dianthi and Fusarium redolens f.sp dianthi. Euro J Plant Pathol 103: 395-408.

11. Vos P, Hogers R, Bleeker M, Reijans M, van de Lee T, et al. (1995) AFLP: a new technique for DNA fingerprinting. Nucleic Acids Res 23: 4407-4414.

12. Kalc-Wright GF, Guest DI, Wimalajeewa DLS, Van Heeswijk R (1996) Characterization of Fusarium oxysporum isolated from carnation in Australia based on pathogenicity, vegetative compatibility and random amplified polymorphic DNA (RAPD) assay. Euro J Plant Pathol 102: 451-457. 
Citation: Almasi MA, Dehabadi SMH, Moradi A, Eftekhari Z, Ojaghkandi MA, et al. (2013) Development and Application of Loop-Mediated Isothermal Amplification Assay for Rapid Detection of Fusarium Oxysporum f. Sp. Iycopersici. J Plant Pathol Microb 4: 177 doi:10.4172/21577471.1000177

13. Hirano Y, Arie T (2006) PCR- based differentiation of Fusarium ff. sp. lycopersic and radicis lycopersici and races of $F$. oxysporum f.sp. Iycopersici. J Gen Plant Pathol 72: 273-283.

14. Notomi T, Okayama H, Masubuchi H, Yonekawa T, Watanabe K, et al. (2000) Loop-mediated isothermal amplification of DNA. Nucleic Acids Res 28: E63.

15. Fu S, Qu G, Guo S, Ma L, Zhang N, et al. (2011) Applications of loop-mediated isothermal DNA amplification. Appl Biochem Biotechnol 163: 845-850.

16. Hadersdorfer J, Neumuller M, Treutter D, Fischer T (2011) Fast and reliable detection of Plum pox virus in woody host plants using the Blue LAMP protocol. Annal Appl Biol 159: 456-466.

17. Mori Y, Notomi T (2009) Loop-mediated isothermal amplification (LAMP): a rapid, accurate, and cost-effective diagnostic method for infectious diseases. J Infect Chemother 15: 62-69.

18. Moradi A, Nasiri J, Abdollahi H, Almasi M (2012) Development and evaluation of a loop mediated isothermal amplification assay for detection of Erwinia amylovora based on chromosomal DNA. Euro J Plant Pathol 133: 609-620.

19. Tsai SM, Chan KW, Hsu WL, Chang TJ, Wong ML, et al. (2009) Development of a loop-mediated isothermal amplification for rapid detection of orf virus. J Virol Methods 157: 200-204

20. Parida M, Shukla J, Sharma S, Ranghia Santhosh S, Ravi V, et al. (2011) Development and evaluation of reverse transcription loop-mediated isotherma amplification assay for rapid and real-time detection of the swine-origin influenza A H1N1 virus. J Mol Diagn 13: 100-107.

21. Hill J, Beriwal S, Chandra I, Paul VK, Kapil A, et al. (2008) Loop-mediated isothermal amplification assay for rapid detection of common strains of Escherichia coli. J Clin Microbiol 46: 2800-2804.

22. Tomita N, Mori Y, Kanda H, Notomi T (2008) Loop-mediated isotherma amplification (LAMP) of gene sequences and simple visual detection of products. Nat Protoc 3: 877-882.

23. Ren WC, Wang CM, Cai YY (2009) Loop-mediated isothermal amplification for rapid detection of acute viral necrobiotic virus in scallop Chlamys farreri. Acta Virol 53: 161-167.

24. Ahmadi S, Almasi MA, Fatehi F, Struik PC, Moradi A (2012) Visual Detection of Potato leafroll virus by One-step Reverse Transcription Loop-Mediated Isothermal Amplification of DNA with Hydroxynaphthol Blue Dye. J phytopatho 161: 120-124.

25. Cardoso TC, Ferrari HF, Bregano LC, Silva-Frade C, Rosa AC, et al. (2010) Visual detection of turkey coronavirus RNA in tissues and feces by reversetranscription loop-mediated isothermal amplification (RT-LAMP) with hydroxynaphthol blue dye. Mol Cell Probes 24: 415-417.

26. Goto M, Honda E, Ogura A, Nomoto A, Hanaki K (2009) Colorimetric detection of loopmediated isothermal amplification reaction by using hydroxyl naphthol blue. Biotech 46: 167-172.

27. Almasi MA, Jafary H, Moradi A, Zand N, Ojaghkandi MA, et al. (2013) Detection of Coat Protein Gene of the Potato Leafroll Virus by Reverse Transcription Loop-Mediated Isothermal Amplification. J Plant Pathol Microbiol.

28. Dukes JP, King DP, Alexandersen S (2006) Novel reverse transcription loopmediated isothermal amplification for rapid detection of foot-and-mouth disease virus. Arch Virol 151: 1093-1106.

29. Iwamoto T, Sonobe T, Hayashi K (2003) Loop-mediated isothermal amplification for direct detection of Mycobacterium tuberculosis complex, M. avium, and M. intracellulare in sputum samples. J Clin Microbiol 41: 2616-2622.

30. Mori Y, Kanda H, Notomi T (2013) Loop-mediated isothermal amplification (LAMP): recent progress in research and development. J Infect Chemother.

31. Dai TT, Lu CC, Lu J, Dong S, Ye W, et al. (2012) Development of a loopmediated isothermal amplification assay for detection of Phytophthora sojae. FEMS Microbiol Lett 334: 27-34.

32. Gadkar V, Rillig MC (2008) Evaluation of loop-mediated isothermal amplification (LAMP) to rapidly detect arbuscular mycorrhizal fungi. Soil Biol Biochem 40 $540-543$

33. Ravindran A, Levy J, Pierson E, Gross DC (2012) Development of a loopmediated isothermal amplification procedure as a sensitive and rapid method for detection of 'candidatus Liberibacter solanacearum' in potatoes and Psyllids. Phytopathol 102: 899-907.
34. Niessen L, Vogel RF (2010) Detection of Fusarium graminearum DNA using a loop-mediated isothermal amplification (LAMP) assay. Int J Food Microbiol 140: 183-191.

35. Niessen L (2013) Loop-mediated isothermal amplification-based detection of Fusarium graminearum. Methods Mol Biol 968: 177-193.

36. Abd-Elsalam K, Bahkali A, Moslem M, Amin OE, Niessen L (2011) An Optimized Protocol for DNA Extraction from Wheat Seeds and Loop-Mediated Isothermal Amplification (LAMP) to Detect Fusarium graminearum Contamination of Wheat Grain. Int J Mol Sci 12: 3459-3472.

37. Denschlag C, Vogel RF, Niessen L (2012) Hyd5 gene-based detection of the major gushing-inducing Fusarium spp. in a loop-mediated isothermal amplification (LAMP) assay. Int J Food Microbiol 156: 189-196.

38. Balogun OS (2007) Evaluation of the Efficiency of the Products of a NonPhenol Chloroform Dna Extraction Method as Templates for Pcr Analysis of Some Fusarium oxysporum Isolates. Am-Euras J Sci Res 2: 141-145

39. Cenis JL (1992) Rapid extraction of fungal DNA for PCR amplification. Nucleic Acids Res 20: 2380

40. Goto M, Shimada K, Sato A, Takahashi E, Fukasawa T, et al. (2010) Rapid detection of Pseudomonas aeruginosa in mouse feces by colorimetric loopmediated isothermal amplification. J Microbiol Methods 81: 247-252.

41. Almasi MA, Moradi A, Nasiri J, Karami S, Nasiri M (2012) Assessment of performance ability of three diagnostic methods for detection of Potato Leafrol virus (PLRV) using different visualizing systems. Appl Biochem Biotechnol 168 : 770-784.

42. Almasi MA, Ojaghkandi MA, Hemmatabadi A, Hamidi F, Aghaei S (2013) Development of Colorimetric Loop-Mediated Isothermal Amplification Assay fo Rapid Detection of the Tomato Yellow Leaf Curl Virus. J Plant Pathol Microbiol.

43. Almasi MA, Erfanmanesh M, Jafary H, Hosseini dehabadi SM (2013) Visual Detection of Potato leafroll virus by One-step Reverse Transcription LoopMediated Isothermal Amplification of DNA with the Genefinder ${ }^{T M}$ Dye. J Viro Methods.

44. Cheng SJ, Chen ZY, Chu YN, Cui LB, Shi ZY, et al. (2011) Sensitive detection of influenza $A(\mathrm{H} 1 \mathrm{~N} 1)$ virus by isothermal amplification in a single tube. Chin $\mathrm{J}$ Anal Chem 39: 335-340.

45. Braid MD, Daniels LM, Kitts CL (2003) Removal of PCR inhibitors from soil DNA by chemical flocculation. J Microbiol Methods 52: 389-393.

46. Kaneko H, Kawana T, Fukushima E, Suzutani T (2007) Tolerance of loopmediated isothermal amplification to a culture medium and biological substances. J Biochem Biophys Methods 70: 499-501.

47. Fukuta S, lida T, Mizukami Y, Ishida A, Ueda J, et al. (2003) Detection of Japanese yam mosaic virus by RT-LAMP. Arch Virol 148: 1713-1720.

48. Soliman H, El-Matbouli M (2009) Immunocapture and direct binding loop mediated isothermal amplification simplify molecular diagnosis of Cyprinid herpesvirus-3. J Virol Methods 162: 91-95.

49. Ma XJ, Shu YL, Nie K, Qin M, Wang DY, et al. (2010) Visual detection of pandemic influenza A H1N1 Virus 2009 by reverse-transcription loop-mediated isothermal amplification with hydroxynaphthol blue dye. J Virol Methods 167 214-217.

50. Ebbinghaus $P$, von Samson-Himmelstjerna G, Krücken J (2012) Direct loopmediated isothermal amplification from Plasmodium chabaudi infected blood samples: inability to discriminate genomic and cDNA sequences. Exp Parasitol 131: 40-44.

51. Francois P, Tangomo M, Hibbs J, Bonetti EJ, Boehme CC, et al. (2011) Robustness of a loop-mediated isothermal amplification reaction for diagnostic applications. FEMS Immunol Med Microbiol 62: 41-48.

52. Niessen L, Gräfenhan T, Vogel RF (2012) ATP citrate lyase 1 (acl1) gene-based loop-mediated amplification assay for the detection of the Fusarium tricinctum species complex in pure cultures and in cereal samples. Int $\mathrm{J}$ Food Microbiol 158: 171-185.

53. Tani H, Teramura T, Adachi K, Tsuneda S, Kurata S, et al. (2007) Technique for quantitative detection of specific DNA sequences using alternately binding quenching probe competitive assay combined with loop-mediated isotherma amplification. Anal Chem 79: 5608-5613. 